\title{
Chora y Alma del Mundo. Una mirada metafísica sobre la obra de Chillida
}

\section{Chora and Anima Mundi. A metaphysical regard on the work of Chillida}

\author{
Ana MARÍA LEYRA \\ Profesora de Estética y Teoría de las Artes \\ Facultad de Filosofía (UCM) \\ aleyra@filos.ucm.es
}

\section{Resumen}

Eduardo Chillida es un artista español cuyas obras han atraído la atención de dos de los pensadores más importantes del siglo XX: Gaston Bachelard y Martin Heidegger. Para ellos tanto las formas del escultor como los procesos mentales y las reflexiones del artista motivaron estudios que han ayudado a comprender el valor y la innovación de los trabajos de Chillida. En continuidad con sus ensayos este artículo pretende responder a algunas preguntas a partir de las esculturas y de las palabras del artista, volviendo a algunos de los antiguos conceptos que el legado filosófico nos ha transmitido: ¿por qué nos emocionan las formas abstractas de Chillida?, ¿por qué empatizamos con ellas?, ¿de qué pasado puede hablarnos ese tipo de arte?

Palabras clave: Empatía, Arquetipo, Chora, Creatividad. 


\begin{abstract}
Eduardo Chillida is a Spanish artist whose works have attracted the attention of two of the greatest thinkers of the $20^{\text {th }}$ century: Gaston Bachelard and Martin Heidegger. Bachelard and Heidegger have dedicated studies both to the sculptures and the mental procedures and reflections of the artist, to explain the value and innovative character of Chillida's works. This article has the aim to give an answer to some of the questions aroused by Chillida's sculptures and writings, turning back to some of the historical concepts that Philosophy has transmitted to us: why do we feel emotionally involved by the abstract forms of Chillida's sculptures? Why do we empathise with them? How can this kind of art recall to us our past?
\end{abstract}

Key Words: Empathy, Archetype, Chora, Creativity.

Para mí esas obras de hierro volante son jaulas-ave, aves-jaula, jaulas que van a remontar el vuelo; pero no obligo a nadie a soñar como yo sueño, a leer como leo el destino de esas obras que realizan una síntesis de la sustancia en movimiento. (...) Lo seguro es que Chillida despierta la meditación del hierro en libertad. (...) Mas, ¿no se encuentran todos esos sueños, sin nosotros saberlo, en nosotros mismos, simples hombres de pálidas manos? ¿No es lo que aqui se nos ofrece un gran sueño de primitivismo humano? Muy lejos, en un pasado que no es el nuestro, viven en nosotros los sueños de la fragua. Es saludable hacerlos revivir.

(Gaston Bachelard, El cosmos del hierro. En El derecho de soñar, pp.56 y ss.)

\title{
1. Los peines del viento. ¿Por qué estas obras de Chillida nos conmueven? La empatía.
}

En el texto con el que abrimos esta reflexión en torno a Eduardo Chillida, Gaston Bachelard se arroga un ejercicio de libertad a la hora de soñar ante las obras del artista. Cada cual debe ejercer, según nos dice este filósofo, su derecho a soñar, a interpretar y a sentir la obra que ha convertido al artista en lo que es, que le ha permitido ser tal, que, diríamos, lo ha consagrado como artista. Esta disposición permite suponer que cualquier intento de interpretar la obra artística, lejos de aspirar a la demostración de la verdad, descansa en la eficacia del ensueño, la rêverie, la ensoñación, que es para el filósofo Bachelard el 
comportamiento genuino del poeta, del artista, en suma del creador; pero ensoñación de la que también es partícipe el contemplador de arte, el público, que acompaña activamente la propuesta que la obra le presenta. Todo lo que sigue no debe ser entendido, pues, de otra manera que no sea la puesta en práctica de mi derecho a soñar a partir de algunas de las esculturas más conocidas de Eduardo Chillida. En este caso voy a reflexionar sobre sus Peines del Viento.

Chillida comenzó la serie de esculturas que llevan el nombre de Peine del viento en 1952 y continuó hasta 1978. Hasta entonces contamos con diecisiete esculturas sobre el tema, y algunas más aparecieron, con posterioridad.

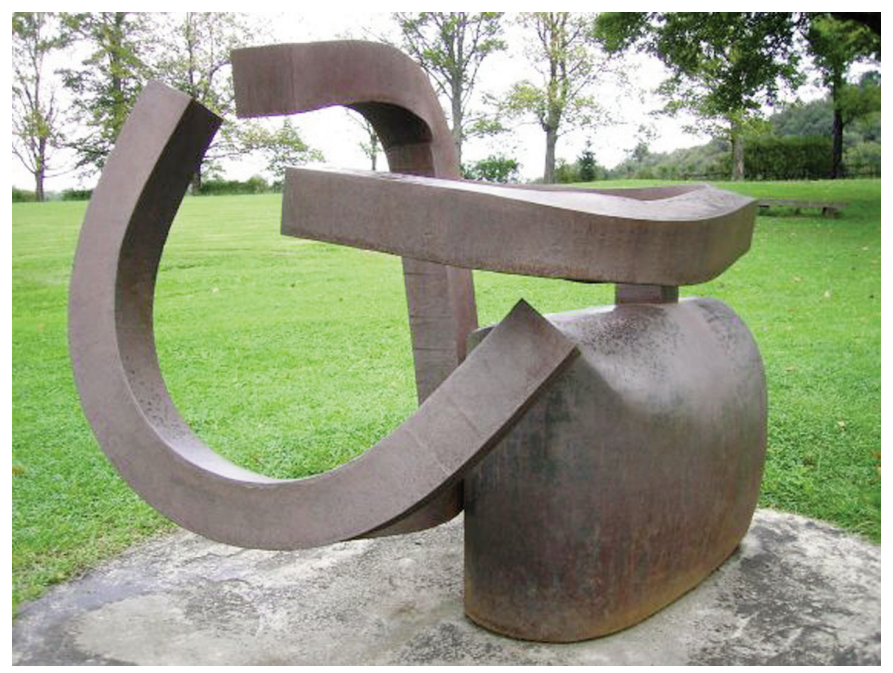

Lo primero que pienso ante estas obras es ¿por qué me emocionan?, ¿por qué emociona una abstracción?, ¿qué mecanismo psíquico desencadena en nosotros una emoción que podemos calificar de gozosa, de placentera, ante las esculturas de Eduardo Chillida? El filósofo y esteta Teodoro Lipps ${ }^{1}$ explica que para el contemplador de arte las formas abstractas aparecen como dotadas de vida, que las líneas geométricas, por muy puras y alejadas de la naturaleza que estén, adquieren para nosotros la eficacia de convertirse en símbolos de fuerzas que nosotros mismos les atribuimos. Esta peculiar atribución de fuerza y de vida a aquello que en realidad carece de vida orgánica es a lo que la estética tradicional y hoy en día las neurociencias han denominado con el término, a partes iguales filosófico, psicológico y científico, de empatía (einfühlung). Se trata de nombrar mediante este término la actividad mental humana encaminada a la constitución de un mundo simbólico por medio de una proyección sen-

${ }^{1}$ Lipps, Th., Estética, Madrid, ed. Jorro, 1915. 
timental, es decir: de la proyección de unos contenidos emocionales que, primero radican en el creador, en el artista, y que, después, la obra es capaz de despertar en quienes la contemplamos. Las formas expresan, hablan, comunican, y por eso conmueven, emocionan, empatizamos con ellas; ahora bien, eso que expresan no resulta fácil de explicar. Por mucha simplicidad de líneas que el objeto con sus formas nos muestre, el arte siempre guarda su secreto y su secreto es lo que provoca el infinito retorno de las interpretaciones, de los desvelamientos, de las búsquedas de la verdad, pero de la "verdad de la obra", siempre deconstruida, siempre por construir.

Por otra parte, la noción de empatía cuenta con una dilatada historia en el ámbito filosófico y en el ámbito meramente estético: primero es objeto de reflexión en el marco de los estudios sobre las emociones en los tratados de la filosofía del empirismo inglés durante el siglo XVIII, después en el ámbito de la psicología y de la estética alemanas de finales del siglo XIX y comienzos del XX, uno de cuyos representantes es el ya citado Teodoro Lipps. En la actualidad esta noción retorna con vigor, formando parte de los estudios que las neurociencias dedican a la reflexión sobre las emociones, la cuestión del bien y el pensamiento que se ocupa de dirimir los efectos de la belleza.

Muchos de los problemas que las filosofías o las ciencias estudian a lo largo de la historia tienen sus precedentes en el arte. Por ejemplo, las nociones de empatía y simpatía las encontramos ya reflejadas desde la antigüedad en la literatura, en concreto en la épica y en la tragedia griegas y, en consecuencia, podemos pensar que alientan en lo más profundo de la sensibilidad humana desde los orígenes de nuestras culturas. Hoy por hoy, la psicología y la biología contemporáneas parten del supuesto de considerar la empatía como un instinto primario, contradiciendo la histórica aseveración de que el ser humano posee, por naturaleza, la agresividad y el egoísmo como instintos básicos para la supervivencia de la especie.

La palabra "empatía" no la podemos encontrar como un concepto plenamente consolidado hasta 1909 cuando el psicólogo estadounidense E. B. Titchener $^{2}$ tradujo al inglés el término Einfühlung, utilizado por la estética alemana. Con anterioridad la noción de simpatía, simpathy, aparece en el ámbito de la filosofía empirista inglesa, aludiendo a la capacidad de "sentir con". A partir del siglo XIX, autores como Robert Vischer, Theodoro Lipps o Johannes Volkelt entienden la empatía como "la proyección de nuestros contenidos emocionales en las cosas". Con ello una línea de estudios estéticos, que lleva el

\footnotetext{
${ }^{2}$ Ver en Changeux, J.-P., Sobre lo verdadero, lo bello y el bien. Un nuevo enfoque neuronal, Buenos Aires, Katz, 2010, p. 112.
} 
sobrenombre de psicologista, relaciona un determinado comportamiento emocional del ser humano con la capacidad de reaccionar frente a la obra de arte o frente a la naturaleza. Según estos autores, somos capaces de disfrutar del arte porque somos capaces de proyectarnos en las obras de arte, capaces de "vivificar" el cuadro, la sinfonía o el paisaje. Es decir: somos capaces de llevar a cabo una atribución de vida a una realidad que en sí misma es inerte, puesto que el otoño no es melancólico, la primavera no es alegre, el arroyo no murmura, etc..., pero les atribuimos nuestro estado de ánimo, nos proyectamos en ellos, llevamos a cabo un acto de Einfühlung, de empatía, de proyección sentimental. Esta corriente estética pronto decae y pasa a ser muy controvertida. Primero se la critica porque da demasiado relieve al sujeto a la hora de analizar los efectos del arte y después, porque la necesidad de huir de excesos románticos y sustituirlos por análisis objetivos de formas y estructuras, provoca el olvido de las aportaciones que en su momento la estética de la llamada Einfühlung o empatía había proporcionado.

En la actualidad un autor, Jean-Pierre Changeux, que fue discípulo de Jacques Monod, y después director de la unidad de biología molecular del Instituto Pasteur y miembro del Collêge de France, dedica en su libro Sobre lo verdadero, lo bello y el bien. Un nuevo enfoque neuronal, (recopilación de investigaciones llevadas acabo en las dos décadas anteriores y publicada en 2008) una gran atención al valor de la empatía, basándose en avanzados estudios sobre cartografía cerebral. Tales estudios permiten mostrar las relaciones del mecanismo psíquico de la proyección de nuestros sentimientos con la capacidad de imitación, de disfrute o de aflicción en un amplio registro de las actividades humanas, el arte y la educación entre ellas. En estos estudios se pone de relieve que:

Recientemente, la investigación sobre las bases neurales de la simpatía se ha visto enriquecida por ciertos resultados sobre las imágenes cerebrales de la percepción del dolor en un individuo sometido a una estimulación dolorosa y en un individuo que observa a otra persona (en excelente relación con él) sometida a la misma estimulación.

Podemos distinguir redes compartidas para el dolor aplicado a uno mismo y al otro y redes propias del dolor sufrido por uno mismo. Por lo tanto es posible una neurobiología de la empatía. ${ }^{3}$

Pues bien, una vez que de nuevo contamos con estudios que nos permiten tener en cuenta el valor de ese mecanismo psíquico de la empatía, que consiste básicamente en poder ponerse en el lugar del otro (algo que por ejemplo el

${ }^{3}$ Ibidem, pp. 112-113. 
individuo psicópata es incapaz de hacer porque es incapaz de establecer vínculos emocionales, de proyectarse en el otro o de sentir con él), podemos proseguir con nuestra interrogación sobre las emociones que suscita en nosotros la obra de arte abstracta y en este caso, en particular, las esculturas de Eduardo Chillida.

\section{El vínculo de la empatía con el arquetipo.}

Atribuimos, pues, vida y contenidos emocionales a las formas inertes, carentes de vida, cuando contemplamos. Ahora bien, antes, ha sido el artista, aquel que ha forjado la obra, el que la hace, quien crea un universo simbólico poblado de imágenes no meramente subjetivas, sino transubjetivas. Son imágenes que se pueden compartir porque emanan de un fondo común, un trasfondo inconsciente que configura nuestras pautas conscientes. Podríamos hablar de un inconsciente colectivo cultural en el que las imágenes arquetípicas tienen la función de comportarse como patrones de comprensión de lo real que subyacen a nuestras estructuras mentales. Utilizando los términos de la psicología jungiana se puede decir que entre el mundo real y el mundo del sujeto encontramos un tercer mundo cuya realidad psíquica no es objetiva ni subjetiva. Lo que nos afecta es la imagen psíquica, la transcripción simbólica tanto de procesos objetivos como de procesos subjetivos.

Todo lo que está en contacto con nosotros no es solo lo que es, sino que al mismo tiempo es un símbolo. La simbolización nace primariamente porque todo hombre tiene contenidos inconscientes y, segundo, porque toda cosa tiene en sí algo desconocido. ${ }^{4}$

Las "cosas" que crea Eduardo Chillida nos emocionan, empatizamos con ellas, porque compartimos ese tercer "mundo", desconocido y a la vez vivido, poblado de símbolos ancestrales. Las imágenes ancestrales del fuego, de la tierra, del aire y del agua están constituyendo la base material de esos procesos inmateriales, espirituales podemos decir, por qué no, que se integran en un todo (materia/espíritu, cuerpo/mente o alma, consciente/inconsciente) a la hora, tanto de dar nacimiento a la obra de arte por parte de su autor, como a la hora de participar del mundo simbólico acaecido por parte de su contemplador.

\footnotetext{
${ }^{4}$ Jung, C. G., Psicología y simbólica del arquetipo, Barcelona, Paidós, 1983, p.94
} 


\section{Los símbolos: De Hefesto (el herrero) a la diosa Mari (el Peine, la Tierra, el Aire, la Gruta, el Agua, el Fuego, la Fertilidad)}

Para Gaston Bachelard es la actividad de la fantasía, una fantasía creadora, la ensoñación, la que al actuar produce las formas, las imágenes mediante las cuales comprendemos y sentimos el mundo que nos rodea. Se trata de una fantasía constituyente que no imita, no reproduce, no representa sino que instaura, produce, crea las imágenes del arte. Al ocuparse de las esculturas de Chillida, Bachelard habla de "sueño de primitivismo humano" y de que "en un pasado que no es el nuestro, viven en nosotros los sueños de la fragua". Con Bachelard son muchos los comentaristas que han percibido en esta lucha del hombre con el hierro y con el fuego que pone ante nuestros ojos Chillida las reminiscencias de los antiguos herreros de los que el trasfondo indoeuropeo de nuestra cultura guarda memoria en el mito de Hefesto, el herrero, el forjador divino de divinos escudos y divinas joyas.

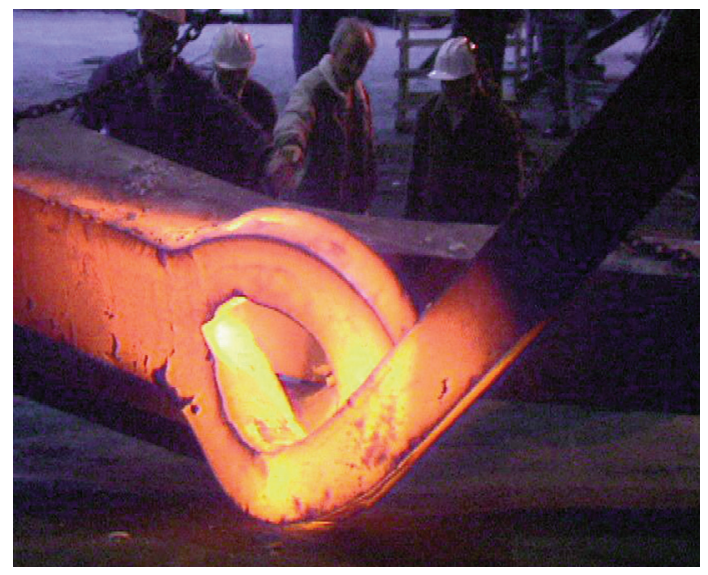

Pero, además del legado cultural indoeuropeo, común a gran parte del continente, existe en el País Vasco un fondo más arcaico, preindoeuropeo, el fondo autóctono de númenes y genios que prestan palabra e imagen a los arquetipos de lo real existente y que se pueden evocar también a partir de la obra, tan moderna, pero a la vez tan intemporal, de nuestro escultor. Existe una divinidad, genio o numen femenino, en el acerbo de la mitología del País Vasco, la diosa Mari, a la que se atribuye la potencia de la fertilidad de la Tierra; que domina y desencadena la tempestad, la lluvia; que ata y desata los vientos; que se muestra en las leyendas con su cabeza rodeada de una corona de fuego, o sobre un globo de fuego, o se muestra ella misma llameante, y cuyo atributo, dorado y mágico, es un peine con el que alisa sus cabellos cuando reposa en las oquedades, en las sagradas grutas por las que emerge de las profundidades de 
la tierra. Mari agrupa y unifica en sí la multiplicidad de lo real, la diversidad de los cuatro elementos. Es al mismo tiempo, la Tierra, el Aire, el Agua y el Fuego, pero lo es como principio integrador-creador, por eso mismo es principio de fertilidad, de vida, principio creativo. ${ }^{5}$

Desde una poética de los contrarios se diría que Mari y su peine son la expresión simbólica y arquetípica de la integración de lo múltiple en lo uno, de la integración de los opuestos en una pertenencia que los reúne sin disolverlos ni aniquilarlos. Sería la imagen simbólica de un universo en tensión cuyo trasfondo no es otro que la Vida emergiendo de una materialidad que tiene que ver mucho más con la noción de physis, la naturaleza, entendida a la manera de los griegos - algo que brota eterna e inagotablemente- que con la idea de una materia, abstracta, estable e inerte.

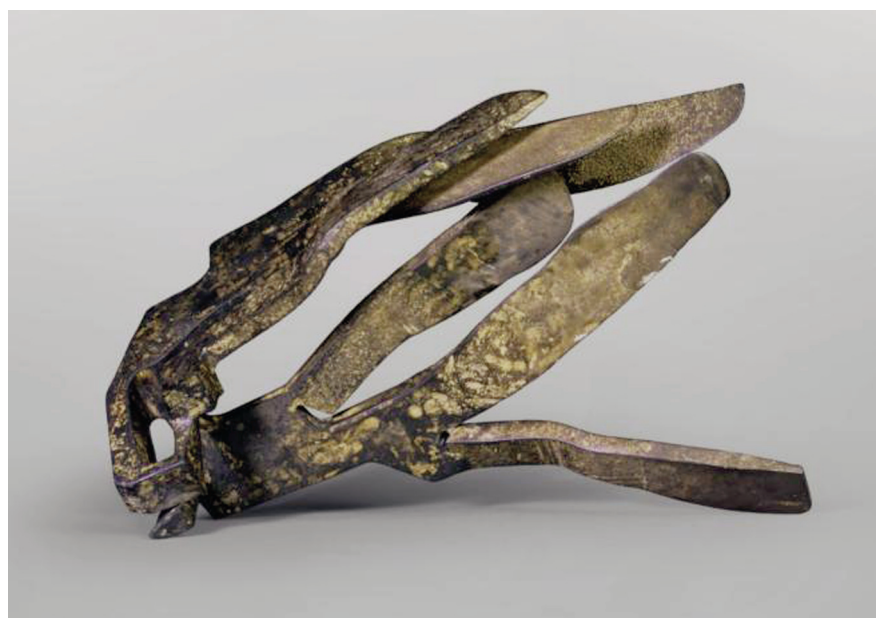

Todo ello se nos da con la claridad de una imagen fantástica cuando admiramos la escultura Peine del Viento III. Las imágenes del peine, del viento, de la cabellera y de un útil de labranza se ofrecen en una intuición simultánea a la mirada del contemplador gracias a una síntesis genial que el artista logra plasmar "a pesar de" y "gracias a" la dureza del material en que se ha realizado. Un mundo de simultaneidad, oposición y contrariedad se armoniza mediante el

\footnotetext{
${ }^{5}$ De Lucrecio (De rerum natura) y Apuleyo (El asno de oro) a Menéndez Pelayo (Una fiesta en Chipre) se ha cantado la fertilidad de la Gran Diosa Madre, así como su metamorfosis en los cuatro elementos, claramente presentes en la Mitología vasca, en la que Mari aparece representando la tierra (lur), el fuego (como sugarra), el agua (como lamia y embrujadora del mar) y el aire (como vaho emergente de sus cuevas). Ortiz-Oses, A. y Mayr, F. H., El inconsciente colectivo vasco. Mitología cultural y arquetipos psicosociales, San Sebastián, Txertoa, 1982, p. 222, nota 2. Ver también De Barandiarán, J.M., Mitología Vasca, San Sebastián, Txertoa, 1979.
} 
tratamiento de las formas. Se lleva a cabo una especie de alquimia visual que logra en un efecto prodigioso la coniuctio, la integración de los contrarios: aire/tierra; levedad/dureza; útil de labranza/instrumento de adorno.

Chillida manifiesta con frecuencia que su lucha al esculpir piezas de gran tamaño es una lucha contra la gravedad. El espacio no sirve solo de marco para la pieza sino que el espacio reclama a la pieza, seduce al artista y nace como entorno, a medida que la idea de la escultura cobra cuerpo y se afianza.

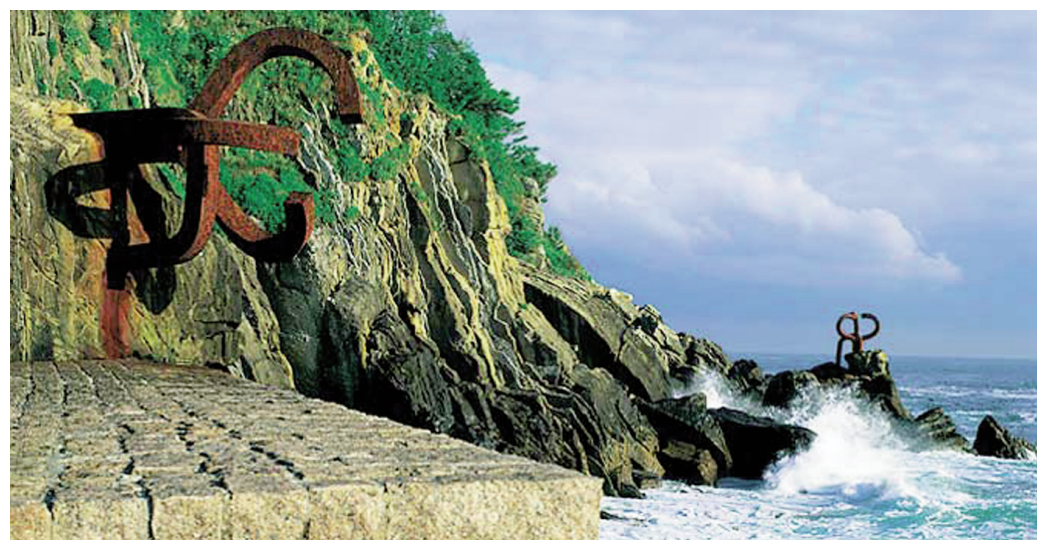

Este lugar es el origen de todo... El verdadero autor de estas obras es él. Yo lo he descubierto y le he hecho un homenaje... me enamoré de ese lugar mucho antes de saber que iba a hacer algo en él... antes de ser escultor... ni siquiera había terminado el bachiller... podría tener catorce años pensando de dónde vendrían las olas... ${ }^{6}$

En principio el proyecto partía de la instalación de una única escultura, pero la evolución mental del proyecto escultórico acaba por imponer un conjunto de tres piezas con una disposición pensada para mostrar en equilibrio dos líneas prevalentes: la horizontalidad que generan, en armonía con el horizonte, las dos esculturas de los extremos, y la verticalidad que rompe el trazo lineal para manifestar con fuerza la gravedad a través de la posición vertical. Nos encontramos así con tres esculturas. Chillida también nos habla del número tres:

Yo siempre estuve muy unido al número tres. De una forma intuitiva, es el medio más económico de entrar en el espacio, la máxima posibilidad de acción elemental sobre el espacio. Así pues, me faltaba un dato y una globalización de todo el problema en función del origen de la idea del Peine del viento del año

\footnotetext{
${ }^{6}$ Fragmentos de la conversación mantenida con Eduardo Chillida en Intz Enea, San Sebastián, en marzo de 1985. En Chillida, E. y Peña Ganchegui, L., El peine del viento, Pamplona, Q Editions, p. 27
} 
$52 \ldots$ Un tercer elemento sobre el horizonte... hacer entrar también la vida del mar... La pieza del fondo, una afirmación hacia el futuro, parece balancearse sobre el horizonte... El Peine del viento es una interrogación ante el futuro... un homenaje al viento, al que admiro mucho, y a mi pueblo, el donostiarra.?

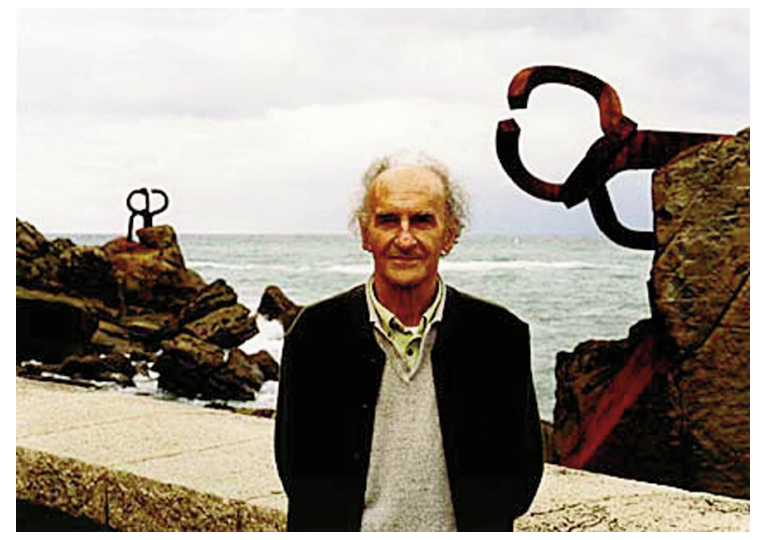

El espacio que rodea el Peine del viento deviene, en consecuencia, un espacio peculiar, originario, casi sagrado, o consagrado, espacio de homenaje a una tierra: la propia.

Esos estratos son testigos de toda la historia de nuestro pueblo, estaban ahí antes que todos nuestros antepasados. Eso me obligó a colocar las dos piezas horizontales, buscándose una a la otra, queriendo unir lo que estaba unido, esto es, unirnos con el pasado, no olvidarnos del pasado. Son un simbolismo del pasado. ${ }^{8}$

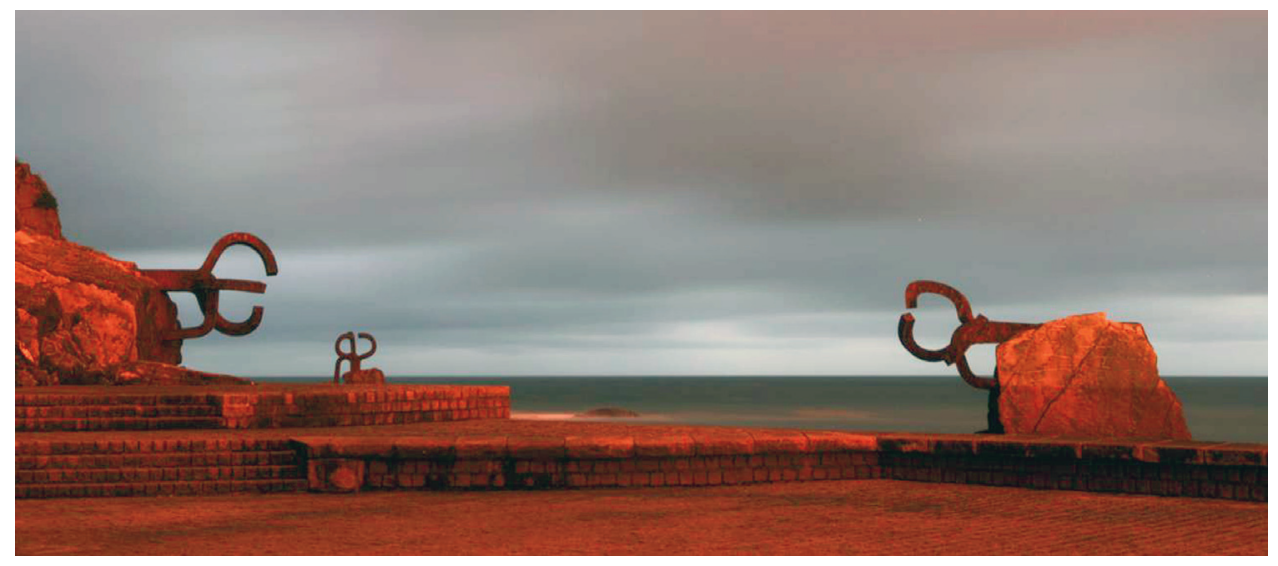

${ }^{7}$ Idem, p. $79-80$

${ }^{8} I d .$, p. 70 
Ahora bien, ya para la tradición pitagórica, que concebía los números como los arquetipos sagrados de la realidad y proponía una comprensión del mundo a partir de una mística del número, el número tres tenía una carga simbólicomística muy específica. Nada podía ser bello si se componía solo de dos partes, el tres confería la belleza, introducía su posibilidad. El número tres era, además, para ellos el número que expresaba lo masculino y que al unirse con la díada femenina, el dos, componían el pentágono místico, expresión de esa unión de los contrarios, masculino/femenino en este caso, que era el símbolo de la coimplicación creativa y también de la vida. ${ }^{9}$

\section{En el Timeo de Platón, Chora expresa un espacio donde se promueve la armonía, la unión de los contrarios en el Todo. El Alma del mundo como mediadora.}

En el Timeo, el más pitagórico de los Diálogos platónicos, Platón explica lo real, el Todo de lo existente, a partir de varios paradigmas: por un lado, un paradigma inteligible, arquetipo ideal, increado y eterno, por otro, una imitación del anterior, Platón dice de este segundo paradigma que está "sujeto a engendramiento", es decir, es creado, y, por último, como mediador de estos dos paradigmas de lo real, un tercero, "Chora", cuya peculiaridad consiste en ser receptáculo para que algo pueda ser. Chora no es ni sensible ni inteligible. Es a la vez lugar y no lugar.

Podríamos visualizarlo espacialmente en una estructura tripartita que podría nombrarlos quizá como "lo de arriba", lo ideal, "lo de abajo", lo material, y una denominación para un algo intermedio, Chora, espacio de lo virtual, espacio-no espacio, receptáculo pleno de virtualidades, ámbito de la posibilidad de ser o matriz de realidad. ${ }^{10}$ Es aquí en ese lugar-no lugar, intermedio e intermediario del Todo de lo real, donde Platón sitúa la formación de los "cuerpos" fuego, aire, tierra y agua. Los elementos de la naturaleza que encontramos bellamente integrados en el conjunto tripartito de El Peine del viento de Chillida en la localidad de San Sebastián.

Por otra parte Platón también nos habla en Timeo (34b) del Alma del Mundo; un concepto a partir del cual digamos que lo inteligible que impregna lo sensible es poietikos, "artista". Por ser el universo sensible objeto de arte es

\footnotetext{
${ }^{9}$ M. C. Ghyka , El número de oro, Barcelona, Poseidón, 2 vols., 1978, y Estética de las proporciones en la naturaleza y en las artes, Barcelona, Poseidón, 1983.

${ }^{10}$ Platón, Timeo 49a - 51d
} 
por lo que puede hablar a la inteligencia, ser objeto de conocimiento. Este nuevo intermediario que explora el Timeo no es sino un eco del gran sistema de intermediarios que colocan la filosofía de Platón fuera del dualismo heredado del eleatismo y de Parménides. La filosofía de Occidente, que concede la primacía, o bien a la inteligencia y a la objetividad de las ideas claras y distintas de la lógica, o bien a la percepción, con la visión de las filosofías empiristas, ha infravalorado el vigor y la fuerza de las imágenes hasta el siglo XIX y sobre todo el XX.${ }^{11} \mathrm{El}$ arte, el imperio de la imagen y de la belleza, manifiesta a través de esta noción de Alma del Mundo platónica el vínculo entre sensible/inteligible o espiritual/material, al romper una dicotomía que colocaba el mundo del arte y de la belleza en un orden de inferioridad respecto a toda posibilidad de conocimiento.

Resumiendo ahora, podemos concluir :

$1^{\circ}$ ) que la noción de Chora, en Platón, califica, nombra un espacio matricial, que no es propiamente un espacio físico. No se trata del espacio de los cuerpos, ya que para este espacio los griegos utilizaban otra palabra: topos, sino que se trata del ámbito de lo virtual, de lo que todavía no es pero hace posible que algo sea.

$\left.2^{\circ}\right)$ que la noción de Chora junto con la noción platónica de Alma del Mundo, que significa que lo inteligible impregna lo sensible artísticamente, creadoramente, son nociones que aluden al carácter intermedio e intermediario de un universo creativo, fondo y a la vez abismo sin fondo, imagen fija de la movilidad de lo viviente; espacio virtual en el que la metafísica platónica nos hace pensar hoy, una vez realizada su clausura pero no al margen de sus aportaciones; espacio que es en el que "se mueven" las búsquedas y los hallazgos de la imaginación del artista.

La historia del pensamiento filosófico de sentido realista nos ha acostumbrado a creer que la metafísica consiste en buscar en la trascendencia un punto de apoyo a partir del cual el cosmos, nuestro mundo físico, reciba una justificación adecuada. Metafísica o cosmología serían el método que nos permita alcanzar, en nuestras lucubraciones, las causas radicales de la realidad. En la filosofía de signo humano, por el contrario, la metafísica no ha de servir a fines metodológicos, sino que ha de brindarnos como objeto aquello mismo en que la trascendencia consiste, ha de mostrarnos el ser y no los entes reales. El revelarse como una irrealidad no ha de invalidar la metafísica; muy al contrario, esa característica suya ha de

${ }^{11}$ Moreau, J., L'Âme du Monde, de Platon aux stoïciennes, París, Belles Lettres, 1939, p. 48. 
ser condición esencial y permanente para que su estudio sea de verdad una metafísica, una disciplina que se ocupa de algo que el mundo físico es incapaz de contener. Está claro que ese mundo irreal al que nos referimos tiene que ser creado, porque no existe, y que, además, tiene que ser autocreado por el hombre, porque solo de sí mismo, y no del cosmos, puede el hombre crear la irrealidad. ${ }^{12}$

Desde estos presupuestos, el término Chora en Platón no posee ninguna determinación, es la expresión de la irrealidad misma, el fondo y abismo a partir del cual las posibilidades de la creación se actualizan.

Jacques Derrida dedica un amplio estudio, Khôra, a dilucidar el carácter profundamente ambiguo de este término y su función eminentemente condicionada por la fuerza de los recursos retóricos del discurso con el fin de proponer que tal concepto pueda ser comprendido al margen de toda caracterización ontológica.

Khôra recibe, para darles lugar, todas las determinaciones pero ella no posee ninguna propia. Las posee, las tiene -puesto que las recibe-, pero no las posee como propiedades, no posee nada propio. No "es" otra cosa que la suma o el proceso de lo que se inscribe "sobre" ella, a propósito de ella, pero no es el sujeto o soporte presente de todas esas interpretaciones, porque, sin embargo, no se reduce a ellas. Este exceso simplemente no es nada, nada que sea y se diga ontológicamente. Esta ausencia de soporte, que no puede ser traducida en soporte ausente o en ausencia como soporte, provoca y resiste cualquier determinación binaria o dialéctica, cualquier examen de tipo filosófico, digamos, más rigurosamente, de tipo ontológico. ${ }^{13}$

El hecho de que las interpretaciones sean innumerables está motivado por su ausencia de ser, por su calidad de mero producto del lenguaje sin atribución de realidad por parte de Platón. Derrida prosigue su análisis: Chora no es ni "sensible" ni "inteligible":

(...) pertenece a un "tercer género" (triton genos, 48e, 52a). Tampoco podemos decir de ella que no es ni esto ni aquello, o que es a la vez esto y aquello. No basta recordar que no nombra ni esto ni aquello o que dice

\footnotetext{
${ }^{12}$ Pajón Mecloy, E., Buero Vallejo y el antihéroe. Una crítica de la razón creadora, Madrid, 1986, p. 631. V. del mismo autor El irrealismo, Madrid, Fundamentos, 2003.
} 
tanto esto como aquello. La ambigüedad declarada por Timeo se manifiesta de otro modo: unas veces la khôra parece no ser ni esto ni aquello, otras veces a la vez esto y aquello. Pero esta alternativa entre la lógica de la exclusión y la de la participación -volveremos extensamente sobre estoproviene tal vez de una apariencia provisional y de las coacciones de la retórica, esto es, de alguna falta de aptitud para nombrar. La khôra parece extraña al orden del "paradigma", ese modelo inteligible e inmutable. Y sin embargo, "invisible" y sin forma sensible, "participa" de lo inteligible de un modo muy dificultoso, en verdad aporético (aporôtata, 51b). ${ }^{14}$

Se trataría de una estructura y no de alguna esencia de la khôra; la cuestión de la esencia deja de tener sentido en relación a ella. ${ }^{15}$

Ante la lectura del Timeo tenemos desde muy pronto la sensación de que se trata de un diálogo extraño, un diálogo que se instala en el mito y parte de un relato anterior, el mito de La Atlántida narrado en la República, pero esta vez recordado, traído a la memoria en los comienzos del Timeo e interrumpido bruscamente, para dar paso a una interpretación cosmológica de lo real por medio de una disertación monológica y que en apariencia provoca en el lector la impresión desasosegante de que Platón se hubiera olvidado de la forma dialógica de lo que estaba narrando. Este diálogo, que parte del relato insertado en otro diálogo, que narra un mito ya narrado, viene a ser un relato de orígenes o sobre los orígenes, genealógico, que desplaza la autoría de lo conocido sobre los orígenes de la cultura griega a un lugar "otro", no griego, a las tierras de Egipto, en el que se gesta el relato. Egipto, territorio real, viene a ser en el diálogo un territorio irreal, territorio "matriz" de una historia, desconocida para sus propios protagonistas, pero historia recuperada tanto como inventada, que convierte ese espacio al que se recurre para obtener la información de la memoria, en territorio "ficcional", no territorio de ficción, sino territorio Chora donde la ficción se crea.

El propio término Chora, susceptible de innumerables interpretaciones, viene a ser diríamos un término funcional, útil para la propia retórica del discurso, pero carente de ser, de existencia real. Derrida lo expresa con precisa claridad:

Se habrá advertido ya que decimos khôra y no, como lo ha querido siempre la convención, la khôra, o incluso, como hubiéramos podido hacerlo

${ }^{13}$ Derrida, J., Khôra, París, Galilée, 1993, pp. 36-37.

14 Ibidem, p. 16.

${ }^{15}$ Id., p. 25. 
por precaución, la palabra, el concepto, la significación o el valor de "khôra". Esto por muchas razones, de las que ciertamente la mayor parte ya son evidentes. El artículo definido presupone ya la existencia de una cosa, el ente khôra al que, a través de un nombre común, sería fácil referirse. Así, lo que decimos de khôra es que este nombre no designa ninguno de los tipos de ente conocidos, reconocidos o, si se prefiere, recibidos por el discurso filosófico, es decir por el logos ontológico que rige en el Timeo: khôra no es ni sensible ni inteligible. ${ }^{16}$

Para nosotros, en este contexto y llegados a este punto, Chora viene a ser el término que nombra la libertad creativa, el origen sin origen a partir del que trabaja y produce sus obras el creador. Algo de lo que no podemos hablar desde la realidad porque no es una cosa; la expresión ambigua de lo que "no es esto ni aquello", de lo que no imita, ni reproduce, pero que "figura" el fondo a partir del cual extrae sus creaciones el artista, el ser humano creador. "Ocupar un lugar y no tener medida: ¿No será esto el espacio?” Se pregunta Chillida, el artista. "Lugar implica dimensión y límites. Pero el punto, lugar por excelencia, no tiene dimensión ni límites." ${ }^{17}$ Para él, para el artista, el ámbito de lo humano es la manifestación de lo abierto, de lo incierto, de lo no pensado: "Trabajo para saber; valoro más el conocer que el conocimiento. Creo que debo aventurarme en hacer lo que no sé hacer. Buscar, visualizar donde no veo, anhelar reconocer lo que no puedo discernir." 18

\section{La unión de los contrarios y más...: finito/infinito, límite/ilimitado, pla- cer/dolor. La belleza y lo sublime.}

Como hemos visto este espacio intermedial de lo imaginario es lugar de encuentro para los opuestos, un espacio en el que se piensan las posibilidades de integrar la multiplicidad en la unidad. Recordando al viejo Heráclito, la formulación de los pares de opuestos se haría inagotable si nos propusiéramos nombrarla de un manera exhaustiva, pero aquí nos interesan dos, especialmente vinculados a las producciones de nuestro escultor. Nos referimos a la idea de límite/ilimitado y al par placer/dolor. Ambos pares de opuestos han sido minuciosamente tratados por gran parte de la filosofía estética a lo largo de nuestra

\footnotetext{
${ }^{16}$ Id., p. 29.

${ }^{17}$ Chillida, E., Escritos, Buenos Aires, La Fábrica Editorial, 2005, pp. 62-64

${ }^{18}$ Ibidem, p. 47.
} 
tradición occidental y en el conjunto escultórico que contemplamos se expresan visualmente con la elocuencia de lo que otro gran artista español, Ramón Gaya, denominaba "el silencio del arte"19. Porque el arte nos habla, pero en silencio.

Los dos pares de opuestos: límite/ilimitado y placer/dolor nos permiten que los analicemos juntos para aplicarlos a una última reflexión estética sobre el Peine de viento. Comenzaremos, pues, por ocuparnos de la noción de límite $\mathrm{y}$ su contraria, la noción de ilimitado o carente de límites.

Para los griegos existía un término, hybris, traducido habitualmente al español como "orgullo", cuyo sentido exacto era el de "extralimitación”. La idea procedía de una concepción de lo humano que quedaba restringida por lo que no era humano, el dios, y también por el animal, de modo que el comportamiento del anthropos, del hombre, debía contar con que sus límites estaban estrictamente señalados: no podía comportarse como un dios porque no lo era, ni como un animal, porque en sentido estricto tampoco lo era. De acuerdo con esta visión del ser humano, el espectador de la tragedia griega sabía, con solo asistir a la representación, que si el protagonista, pongamos como ejemplo a un Agamenón, consentía en recibir los honores reservados para los dioses, cometía hybris, se saltaba su límite y sería castigado por la divinidad, y de igual modo si su comportamiento le llevaba a mostrarse presa de una animalidad que no le correspondía. Es el caso de un Ayax invadido por la crueldad y comportándose como una fiera al confundir rebaños con soldados. Se puede decir, en consecuencia, que la noción de límite entre los griegos era una noción antropológica, inherente a la condición de humano. Ahora bien, históricamente la noción de límite, al evolucionar, también se ha podido comprender desde otras perspectivas. En momentos posteriores de la filosofía, autores como Burke o Kant eligen para reflexionar sobre el arte una distinción entre los efectos de la belleza en quien la contempla, efectos experimentados en proporción a las condiciones de la naturaleza humana, y los efectos de la contemplación de la inmensidad de la naturaleza, dado el carácter limitado de nuestros sentidos, ya que la posibilidad de dilatar nuestra capacidad de ver, de oír, o incluso de nuestra resistencia física, es realmente limitada. Ya no estamos en una época que se preocupa por fijar la atención en no ser como el dios o como el animal, sino que fija su atención en lo que en realidad somos: individuos de condición débil, limitada frente a los poderes de la naturaleza. La toma de conciencia filosófica de esta circunstancia se da asociada al dolor que produce el reconocimiento de nuestra condición de limitados. Dolor que en el caso del

${ }^{19}$ Gaya, R., Obra Completa, Valencia - Madrid, Pre-Textos, 2010, p. 66. 
arte va a encontrar una salida, más bien una fisura, cuando frente al hecho de sentirnos limitados, en un segundo momento, que elimina esta aflicción, aparece en el ser humano la capacidad de superar los límites de los sentidos mediante una facultad en nosotros que nos permite afrontar gozosamente la experiencia de la superioridad de la naturaleza. A la experiencia de este enfrentamiento entre el dolor por el límite y el placer por la posibilidad de concebir lo ilimitado le aplica Kant un viejo término heredado de la retórica clásica y califica el sentimiento que suscita de "sentimiento de lo sublime".

Ahora bien en el pequeño tratado Sobre lo sublime (Perí Hypsous) ${ }^{20}$ se manifiesta que la idea de grandeza, la sublimidad, que la retórica trata, tiene su origen también en la naturaleza, pero en la naturaleza "humana": Lo sublime es, para el desconocido maestro de retórica, autor del texto, el eco de un espíritu noble. ${ }^{21} \mathrm{Y}$ allí se concluye:

Por esto, para el ímpetu de la contemplación y del pensamiento humano no es suficiente el universo entero, sino que con harta frecuencia nuestros pensamientos abandonan las fronteras del mundo que les rodea $\mathrm{y}$, si uno pudiera mirar en derredor la vida y ver cuán gran participación tiene en todo lo extraordinario, lo grande y lo bello, sabría, en seguida, para qué hemos nacido. ${ }^{22}$

Aquella noción que Kant transforma de sentimiento exclusivamente estético en sentimiento moral en cuanto experiencia de lo suprasensible, había nacido en el mundo clásico para dar cuenta de las capacidades del individuo creador y, en consecuencia, de la necesidad implícita en todo gran arte y en todo gran artista de transgredir los límites, de confrontar su humana condición con la naturaleza y de proyectar la propia grandeza fuera de sí mediante su obra.

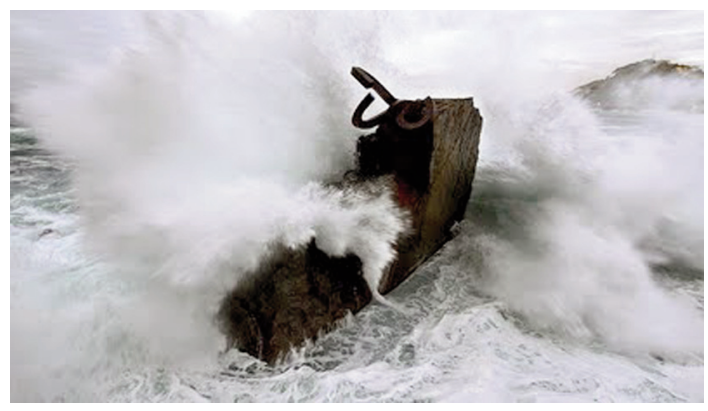

${ }^{20}$ Longino, Sobre lo sublime, Madrid, Gredos, 2008.

${ }^{21}$ Ibidem, p. 160.

${ }^{22} I d$. p. 202 y ss. 


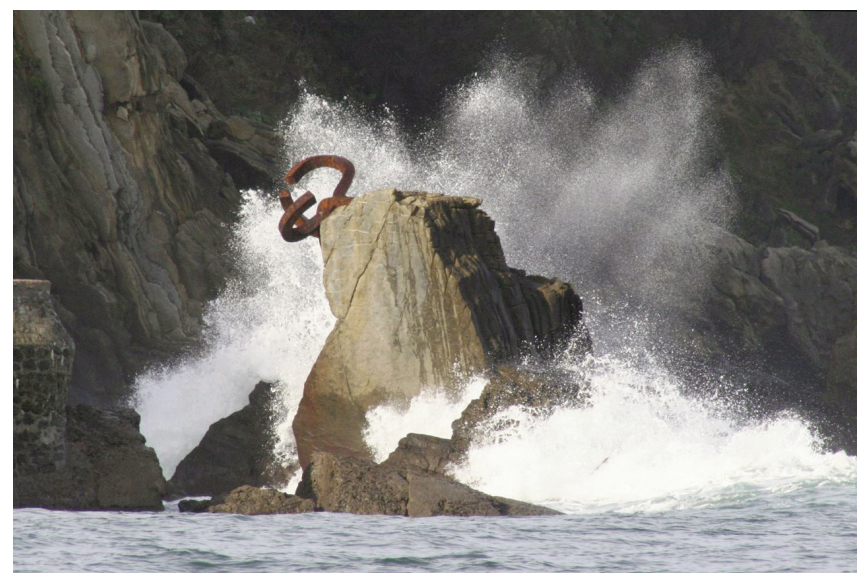

\section{Y de nuevo: ¿por qué nos conmueven?}

Llegados a este punto es necesario volver al comienzo y a la pregunta que nos guiaba: ¿por qué nos emocionan estas obras de Chillida? Diríamos que en ellas el ser humano que las contempla está llamado a sentir al mismo tiempo su infinita pequeñez y su grandeza, que el desafío de la naturaleza se hace, al mismo tiempo, amenazador y fascinante. En ellas se hacen presentes, en la evidencia de una imagen, emociones arcaicas que emergen de un pasado que nos constituye, se hace presente la naturaleza humana. Nada como la inserción de estas moles sobre la piedra y frente al mar, bajo el cielo, puede manifestar con mas fuerza la capacidad humana de llegar más lejos, de romper los límites. Y también de mostrarnos lo que decía Bachelard al hablar de las esculturas de Chillida en la cita que al principio hemos utilizado:

\footnotetext{
Mas, ¿no se encuentran todos esos sueños, sin nosotros saberlo, en nosotros mismos, simples hombres de pálidas manos? ¿No es lo que aquí se nos ofrece un gran sueño de primitivismo humano?(...) Es saludable hacerlos revivir.
}

Es algo que ha entendido muy bien María Zambrano al reflexionar sobre las transformaciones del gusto después de la aparición de las vanguardias en el arte europeo. La pérdida de la figuración, ¿era realmente una pérdida o, por el contrario, suponía el hallazgo de nuevos cauces para la mirada, para la sensibilidad y para el pensamiento? Sin lugar a dudas, para ella las nuevas formas ponían a disposición del contemplador aspectos imprescindibles que renovaban la experiencia cultural de la época: 
(...)Volvían a mostrarse cosas que la humanidad no recordaba; un pasado remoto dejado atrás vivía de nuevo. Viejísimos dioses debieron sonreír y miles de potencias vencidas debieron acudir, ligeras, a la llamada. ${ }^{23}$

Haciendo nuestras las palabras de Bachelard y de Zambrano y reivindicando el derecho a soñar, nos permitimos aquí, ahora, al proyectarnos en las obras de Chillida, al empatizar con ellas, al llenarlas de vida, de nuestra vida, traer a la memoria aquellos dioses y hacer revivir aquellos sueños.

${ }^{23}$ Zambrano, M., Algunos lugares de la pintura, Madrid, Eutelequia, 2012, p. 21. 